\title{
「固体高分子形燃料電池の可視化」特集にあたっで*
}

\author{
山内 慎**, 船谷 俊平***
}

\section{Visualization Techniques in Polymer Electrolyte Fuel Cell}

\author{
Makoto Yamauchi and Shumpei Funatani
}

燃料電池は, 燃料極（アノード）に水素, 空気極（力 ソード）に酸素（実際には空気）を供給することで，電 気化学反応によって直接電気エネルギーを取り出すこと ができ，全体の反応による生成物は水だけであることか ら，高効率で環境負荷が低い発電システムとして注目さ れている．燃料電池は用いる電解質材料によって分類さ れており，現在実用化されている，あるいは，研究開発 されているのは次の 4 種類が代表的である. 燃料電池の 作動温度の高い順から, 固体酸化物形燃料電池 (SOFC), 溶融炭酸塩形燃料電池 (MCFC), リン酸形 燃料電池 (PAFC), 固体高分子形燃料電池 (PEFC) で ある. 現在, 家庭用分散型電源として売り出されている エネファーム (ENE・FARM; 家庭用燃料電池コー ジェネレーションシステム）は，動作温度がこの中では 最も低い PEFC が搭載されている，燃料である水素は, LPG, 都市ガス, 灯油から改質し, 酸素はその場の空気 を加湿器・フィルタを介して供給されている，高温型の SOFC に関しても，実証試験が 2010 年度までの 4 年間 で実施され (現時点でも百数十台が稼働中), 高温型の 特長を活かした性能が得られる可能性が示唆され, シス テム要素技術開発の段階となっている。 PEFCは 2015 年度以降の本格普及機への適用に向けて, システムの大 幅なコストダウン（定置用 $1 \mathrm{~kW}$ 級でメーカー出荷額 50 70 万円） と耐久性（ 6 万時間）が求められており, システム全体の研究開発が行われている。 その実現のた めの計測・解析技術が求められており, 本特集では, PEFCにおける水の「可視化」に着目した.PEFCは動 作温度が低いため, システムの起動・停止性は優れてい るが, 発電反応により生成する水は液体の水として存在 でき, その液水が $\mathrm{PEFC}$ の性能劣化要因の 1 つとなっ ている。そのため, PEFCの水管理は重要な課題であり, 本特集では, PEFCの液水挙動を把握するための可視化

* 原稿受付 2011 年 8 月 31 日

** 正会員 大阪府立大学工業高等専門学校 総合工学システム学 科 機械システムコース（５ 572-8572 大阪府寝屋川市幸町 26-12, E- mail : yamauchi@osaka-pct.ac.jp)

*** 正会員 山梨大学大学院 医学工学総合研究部工学領域 機械 システム工学専攻（言 400-8511 山梨県甲府市武田 4-3-11, E-mail : sfunatani@yamanashi.ac.jp)
技術とその計測事例を紹介する。

ENEOS セルテックの福永氏, 鈴木氏には, エネファー ムのメーカーとして, PEFCの水をキーワードとした MEA（Membrane electrode assembly）開発に関する解 説と，メーカーの視点から可視化技術に期待することを 紹介いただいた。本格普及機用の電池スタック運転温度 は 80 $90^{\circ} \mathrm{C}$, アノード低加湿, カソード無加湿化を目指 しており，MEAの高温，低・無加湿化に向けた実験結 果を示していただいた. PEFC はアノードとカソードのガ ス流路をもつカーボンまたは金属セパレータの間に MEA を挟み込む構造であるため, 発電中の PEFC 内部を可視 化するには工夫が必要である。神戸大の竹中先生には, 中性子ラジオグラフィによる金属製セパレー夕内部の液 水分布の計測事例を紹介いただいた。通常，PEFCは要 求される出力に応じてシングルセルを直列に接続して積 層する「スタック」として使用する。発電反応は発熱反 応であることから，スタック内部では温度分布が生じる。 スタック内部の水分布把握のためのダイナミック CT 計 測法を開発し，3セルスタック内部の流路内水の 3 次元 分布の結果を示していただいた，東工大の津島先生，平 井先生には, 磁気共鳴イメージング (MRI) による電解 質膜内の水分布の計測事例と, MRI 計測では把握できな かった電解質膜の両面にある触媒層やガス拡散層 (GDL) 内の水分布計測のために開発した軟 X 線による 電極内水分布の計測事例を紹介いただいた。本結果は, $\mathrm{PEFC}$ の水移送特性把握の上で非常に有用な技術であり， MEA 設計用に期待されている. 山梨大の犬飼先生, 渡 辺先生には, PEFC 内部の液水分布だけでなく酸素分圧 を同時に把握する可視化技術について紹介いただいた。 過剩水が GDL から排水され，ガス流路中で閉塞するプ ラギング発生前後の酸素分圧結果から, 流路閉塞箇所を 避けて GDL 内をガスが通過するという従前の説明を裏付 ける結果が示されている。千葉工大の江尻先生には，燃 料電池システムに期待されている自立型電源（災害時） 用や可搬用のパッシブ型 PEFC（常温, 無加湿, カソー ド大気開放）に関するカソードの生成水や温度分布，空 気流の PIV 計測事例を紹介いただいた。パッシブ型の電 池性能は, カソードの酸素供給量がポイントであり, 自 然対流により酸素が供給されている結果が示されている. 